\title{
Antimicrobial activity of Tetrodotoxin extracted from liver, skin and muscles of the puffer fish Lagocephalus sceleratus inhabiting Mediterranean Sea, Egypt.
}

\author{
Ahmed N. Alabssawy \\ Marine Science \& Fishes Branch, Zoology Department, Faculty of Science, Al-Azhar University, Cairo, Egypt.
}

ABSTRACT

Tetrodotoxin (TTX) is a strong marine toxin which is a powerful sodium channel inhibitor. So far, there is no known antidote for TTX to block its toxicity. Therefore, the main aim of this study was to isolate and characterize TTX from the puffer fish, Lagocephalus sceleratus ( $L$. sceleratus) in cold and warm seasons and test its antimicrobial activity. The obtained results showed antibacterial and antifungal activity of the crude extracts of TTX isolated from liver, skin and muscles of $L$. sceleratus. TTX isolated from of the liver extract showed broad-spectrum antibacterial activity where it showed its maximum activity against Escherichia coli (22.24 mm \pm 0.96$)$ as gram negative bacteria and against Bacillus subtilis ( $17.51 \mathrm{~mm} \pm 0.51$ ) as gram positive bacteria. Its minimum activity, however, was shown against Vibiro cholerae $(9.22 \mathrm{~mm} \pm 0.65)$. The hepatic TTX extract showed its maximum antifungal activity at $19.21 \mathrm{~mm} \pm 0.59$ against Aspergillus fumigatus where TTX extract from skin showed its minimum activity against Trichophyton rubrum at 5.33 $\mathrm{mm} \pm 0.52$. The highest TTX levels in the livers, skins and muscles of female fish were found in winter $(30.33,3.38$ and $2.26 \mu \mathrm{g} / \mathrm{g}$ respectively). The TTX level in the muscle of male fish in summer was $0.66 \mu \mathrm{g} / \mathrm{g}$ but was otherwise below the toxic limit. The present study indicates to that TTX from $L$. sceleratus possesses antimicrobial activities, which depends on the season and sex.

\section{ARTICLE INFO}

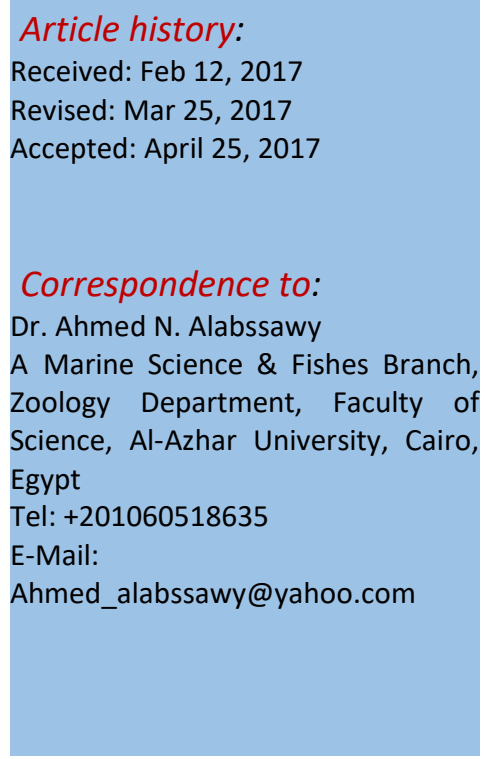

Keywords: Antimicrobial - Antibacterial - Antifungal - toxicity - Puffer fish - Lagocephalus sceleratus Tetrodotoxin.

\section{INTRODUCTION}

The bio resources present in the marine ecosystem have potent biomolecules which includes many natural organic compounds. These compounds are reported to have biological activities like anti- tumor, antiviral and analgesic (Rajamanikandan et al., 2011). Marine fish are also of high nutritive value. Proteins from fish have shown biological activities like anti- bacterial, anti- inflammatory and antioxidant (Khora, 2013).

Fish live in intimate contact with an environment containing pathogenic organisms. The slow adaptive immune response of fish makes innate immunity, which is fast acting and temperature independent predominant system of fish host defence (Ellis, 2012). The defence includes many elements such as antimicrobial peptides, lipids and polypeptides (Ravichandran et al., 2010).

Tetrodotoxin (TTX) is a strong marine toxin, which is a powerful sodium channel inhibitor (Hwang and Noguchi, 2007). TTX is thermo-stable and also cannot be removed by washing (Noguchi and Ebesu, 2001). So far, there is no known antidote specific for TTX that can block its biological activities. Although TTX was first isolated from puffer fish, it has been 
found in other marine organisms and a few terrestrial species (e.g., newt and frog) (Miyazawa and Noguchi, 2001).

TTX is a new phenomenon for Mediterranean countries as $L$. sceleratus (Gmelin, 1789) invaded the Mediterranean Sea. L. sceleratus has had negative ecological, economical, and health effects in the Mediterranean basin (Aydin, 2011; Streftaris and Zenetos, 2006). It was reported that this species was high in protein and had a favourable fatty acid profile (Aydin et al., 2013).

Furthermore, puffer fish may be a threat to public health if they contain TTX. According to current European Union (EC, 2004) and Turkish regulations, the landing, sale and consumption of puffer fish is prohibited. Although this fish is poisonous, it is consumed in some countries, including Mediterranean countries, such as Turkey, Egypt and Lebanon (Aydin, 2011; Chamandi et al., 2009 and ElSayed et al., 2003).

The current study was undertaken to isolate, identify and evaluate the antimicrobial activities of TTX isolated from three organs, including the liver, skin and muscles of the puffer fish against different bacteria and fungi strains. The results indicated that its antimicrobial effects are season and sex dependent.

\section{MATERIALS AND METHODS}

\section{Sampling}

A total of 20 specimens ( 12 males and 8 females) of the puffer fish, $L$. sceleratus (Gmelin, 1789), ranging between $14.34-45.78$ $\mathrm{cm}$ in total length and $50.90-3820 \mathrm{~g}$ in weight, were captured by commercial bottom trawlers using purse seine nets. The investigated area was at 24 and 50 meter depths in the Egyptian coast of eastern Mediterranean Sea from ElHammam to Rosetta $\left(31^{\circ} 00^{\prime} \& 31^{\circ} 50^{\prime} \mathrm{N}\right)$ and $\left(27^{\circ} 00^{\prime} \& 31^{\circ} 40^{\prime} \mathrm{E}\right)$. The fish were captured in January 2016 (the coldest month in winter season) and in n July 2016 (the warmest month of summer season). Directly after collection, the fresh samples were weighed and immediately frozen at $-20^{\circ} \mathrm{C}$. Then, they were transported to the Laboratory of Marine Biology in Zoology Department, Faculty of
Science, Al-Azhar University, Cairo, Egypt where they were taxonomically identified according to Randall (1983).

\section{Isolation and partial purification of toxin}

Organs pooled from all specimens were collected (2430 g liver, 12,321 g muscles, 2356 g skin). Portion (10g) of the muscle, liver and skin were extracted with $25 \mathrm{ml} 1 \%$ acetic acid (Merck) and homogenized separately. Each homogenate was heated for 10 minutes in a boiling water bath (Memmert, Schwabach, Germany) with occasional stirring. The mixture was cooled to the room temperature $\left(23-24^{\circ} \mathrm{C}\right)$ and then filtered with Whatman $110 \mathrm{~mm}$ filter paper (Sigma-Aldrich, Lyon, France). The residue on the filter paper was washed with $0.1 \%$ acetic acid followed by centrifugation at $5000 \mathrm{rpm}$ for 15 minutes. This step was carried out three times to extract the toxin. The obtained supernatant was concentrated using rotary evaporator, the final solution, of which 1 $\mathrm{ml}$ was equivalent to $0.2 \mathrm{~g}$ of tissue and stored at -20 o $C$ for further use (Khora, 1991).

\section{Tested organisms}

Bacterial species such as Staphylococcus aureus, Bacillus subtilis, Streptococcus agalactiae and Enterococcus faecalis (gram positive bacteria) and Vibiro cholerae, Aeromonas veronii, Escherichia coli, Proteus vulgaris, Salmonella typhi and Shigella dysenteriae (gram negative bacteria) were maintained in Luria Bertani broth. Fungal species such as Candida albicans, Aspergillus fumigatus and Trichophyton rubrum were maintained in Potato dextrose broth.

\section{Tetrodotoxin (TTX) standard}

TTX standard was purchased from Sigma-Aldrich, USA. Standard solutions of TTX were prepared with methanol (Merck) and stored at $-20^{\circ} \mathrm{C}$ until used. All chemicals used were of analytical grade, solvents for HPLC and TLC from El-Nasr Co., Egypt. Also, all analytical experiments for TTX were conducted in Analytical Chemistry Laboratory of Analytical Chemistry Department, Faculty of pharmacy, Al-Azhar University, Cairo except TTX levels $(\mu \mathrm{g} / \mathrm{g})$ using LC-MS-MS were conducted in 
Analytical Central Lab. which belong to Faculty of pharmacy, Cairo University.

\section{Thin-layer chromatography (TLC) of toxins}

TLC was performed on silica gel 60F254 pre-coated plates (Merck) with the butanol: acetic acid: water $(2: 1: 1 \mathrm{v} / \mathrm{v})$ solvent system. After development, the plates were sprayed with $10 \% \mathrm{KOH}$. The plates were then heated at $110^{\circ} \mathrm{C}$ for $10 \mathrm{~min}$, according to (Onoue et al., 1984). The experiment was conducted by Dr. Ahmed Serag, in Department of Analytical Chemistry, Faculty of pharmacy, Al-Azhar University, Cairo.

\section{Antimicrobial activity}

Antimicrobial activity was determined using the agar well diffusion assay method as described previously (Holder and Boyce, 1994). The tested organisms were sub cultured on nutrient agar medium for bacteria and Saboroud dextrose agar for fungi. Ampicillin for gram positive bacteria and Gentamycin for gram negative bacteria were used as a positive control for bacterial strains. Fluconazole was used as a positive control for fungi. The cultures were done in triplicate. Bacterial cultures were incubated at $37^{\circ} \mathrm{C}$ for $24 \mathrm{~h}$ while the other fungal cultures were incubated at 25$30^{\circ} \mathrm{C}$ for 3-7 days. The Antimicrobial activity was determined by measuring the zone of inhibition. The percentage of inhibition of cell growth was calculated as follows:

Percentage of inhibition $=100-($ Sample $)$

$$
\text { Control) } \times 100
$$

\section{Sample extraction for the LC-MS-MS analysis}

Analysis was carried out as previously described (Silva et al., 2012). Tissue sample (1 g) of muscle, liver and skin was extracted with $3 \mathrm{ml}$ of $1 \%$ acetic acid. Then, the solution was homogenized using the homogenizer at 2400 rpm for 10 min (IKA T25 Digital Ultra Turrax, Staufen, Germany) followed by an ultrasonic bath (Bandelin Sonorex RK 100, Berlin, Germany) for $10 \mathrm{~min}$ at $100 \mathrm{~Hz}$. Two additional homogenization (2400 rpm, $10 \mathrm{~min}$ each) were done and the extract was centrifuged at 4500 rpm for $20 \mathrm{~min}$ at $4^{\circ} \mathrm{C}$ (Hettich Zentrifugen, Universal 32R, Tuttlingen, Germany). Supernatants were combined and adjusted to a final volume of $7 \mathrm{ml}$. After that, $1 \mathrm{ml}$ of the extract was cleaned by running through a 500 $\mathrm{mg} / 3 \mathrm{ml}$ C18 solid-phase extraction (SPE) cartridge (Supelco, Bellefonte, PA, USA). The sample was eluted with $10 \mathrm{ml}$ of $100 \%$ methanol and diluted with the same solvent to a final volume of $12 \mathrm{ml}$. Finally, each sample was concentrated by drying (Buchi, Rotavapor R-3, Flawil, Switzerland) and re-suspended in 1 $\mathrm{ml}$ of methanol, and the sample $(100 \mu \mathrm{l})$ was filtered through a $0.45 \mu \mathrm{m}$ membrane filter (Clarinet, Agela Technologies, Wilmington, USA) before LC-MS/ MS analysis.

\section{UV Spectrophotometer}

Shimadzu

UV-Visible

1650

Spectrophotometer, (Tokyo, Japan), equipped with $10 \mathrm{~mm}$ matched quartz cells was used.

\section{HPLC (High Performance Chromatograph)}

HPLC, constaMetric ${ }^{\circledR} \quad 4100$ LDC analytical pump (Milton Roy, USA), equipped with Spectra system UV3000 diode-array UVVisible detector and spectra system AS3000 auto sampler was used. The chromatographic analysis was carried out using (ChromQuest 4.2.34, version 3.1.6) data analysis program.

\section{Chromatographic conditions}

At ambient temperature, isocratic separation was carried out on Supelco C18 column $(25 \mathrm{~cm} \times 4.6 \mathrm{~mm}, 5 \mu \mathrm{m}$ particle size $)$ using mobile phase consists of acetonitrile: methanol: water (50:30:20, by volume). The mobile phase was degassed by a degasser before pumped at flow rate of $1 \mathrm{ml} / \mathrm{min}$. The injected volume of the standard solution was $20 \mu \mathrm{l}$ and UV detection at $220 \mathrm{~nm}$.

\section{Statistical analyses}

Data were computerized and analyzed using SAS Version 9 statistical package (SAS, 2002), the analysis was revised and graphics were drawn by Excel for Microsoft office 2010. The obtained data were assessed by calculation of the mean (M) and standard deviation (SD) was calculated using multiple linear regressions (Finney, 1971).

\section{RESULTS}

\section{Analysis of TTX by LC-MS-MS}

The maximum amount of TTX in females livers tissues followed with males livers tissues using 
LC-MS-MS were 30.33 and $25.37 \mu \mathrm{g} / \mathrm{g}$ respectively (Table 1 ). TTX in muscle tissues was found above $2 \mu \mathrm{g} / \mathrm{g}$ only in a female fish, only in the winter $(2.26 \mu \mathrm{g} / \mathrm{g})$, TTX levels in the skins exceeded $3 \mu \mathrm{g} / \mathrm{g}$ for females in winter, although for males were $<2 \mu \mathrm{g} / \mathrm{g}$ in winter and summer. The TTX levels in the liver (of those fish analyzed) exceeded $2 \mu \mathrm{g} / \mathrm{g}$ for females in the summer and become highly toxic as $(21.04 \mu \mathrm{g} / \mathrm{g})$ than males were $(4.04 \mu \mathrm{g} / \mathrm{g})$ in the same season as showed in Figures 1 and 2 .

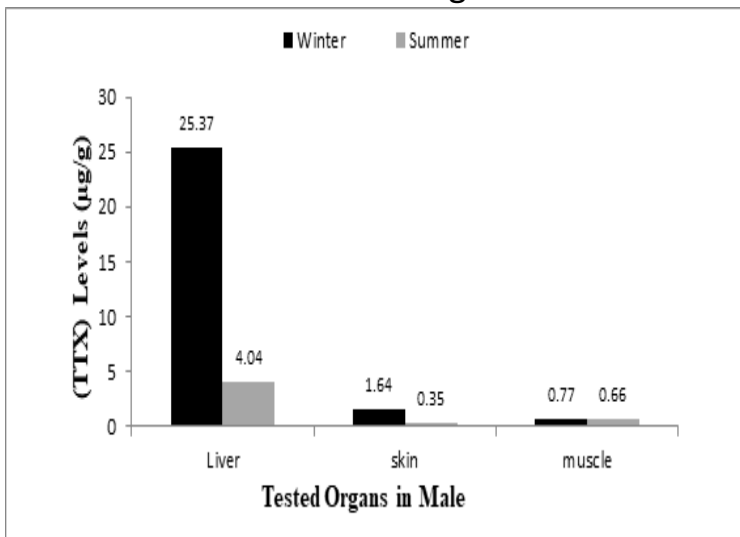

Figure 1. Seasonal TTX levels in different tissues isolated from males of Puffer fish, $L$. sceleratus ( $\mu \mathrm{g} / \mathrm{g}$ ) using LC/MS/MS.

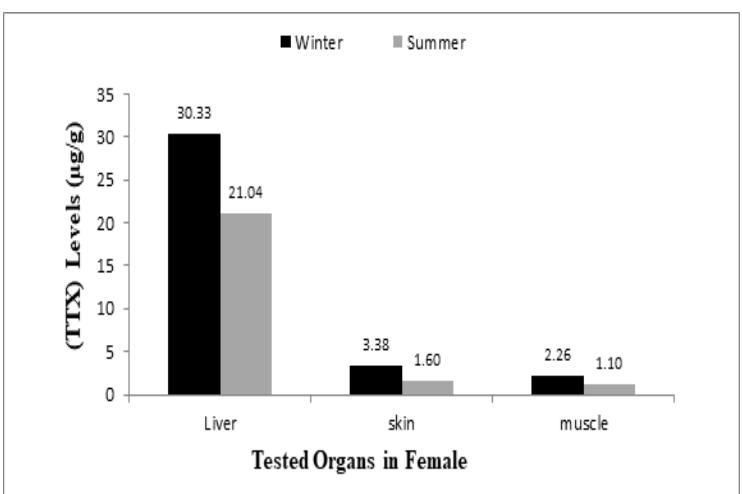

Figure 2. Seasonal TTX levels in different tissues isolated from females of Puffer fish, $L$. sceleratus $(\mu \mathrm{g} / \mathrm{g})$ using LC/MS/MS.

\section{Analysis of TTX by HPLC}

HPLC analysis allowed the separation and sensitive detection of individual TTX and its analogs irrespective of their number and group. Therefore, HPLC methods opened up a new dimension in TTX analysis. Additionally, accurate HPLC determination of the various TTX components in the samples is a necessity. Using these methods, the toxic principles produced peaks identical to those of authentic TTX and its derivatives. The HPLC method utilizes a computer controlled by a high pressure pump with a syringe loading sample injector or an auto-sampler system, a stainless steel column, a reaction pump for delivering reagents, and a monitor and chromatorecorder for calculation of the peak area. The treated toxins are identified by comparing their retention times with those of authentic TTX (Figures 3 and 4).

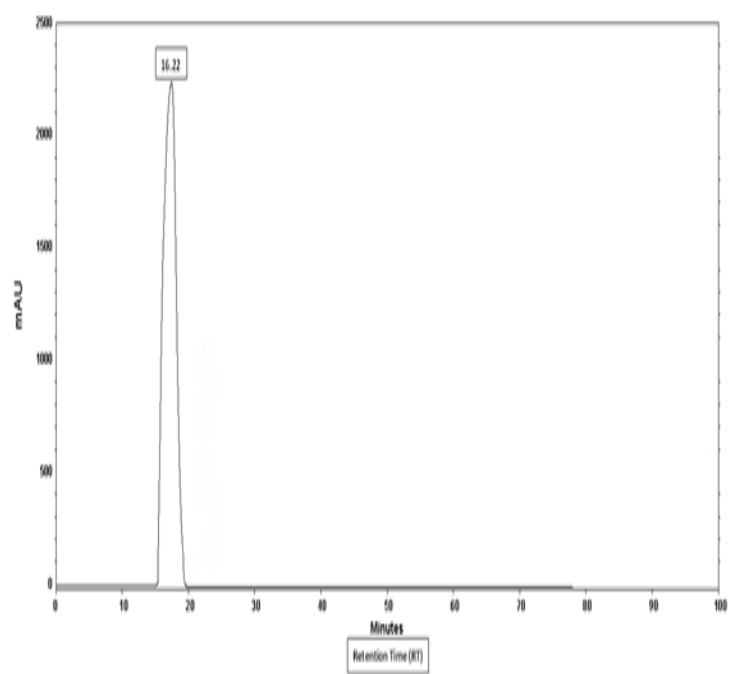

Figure 3. HPLC analysis of TTX in the liver of toxic Puffer fish, Lagocephalus sceleratus from Mediterranean sea, Egypt.

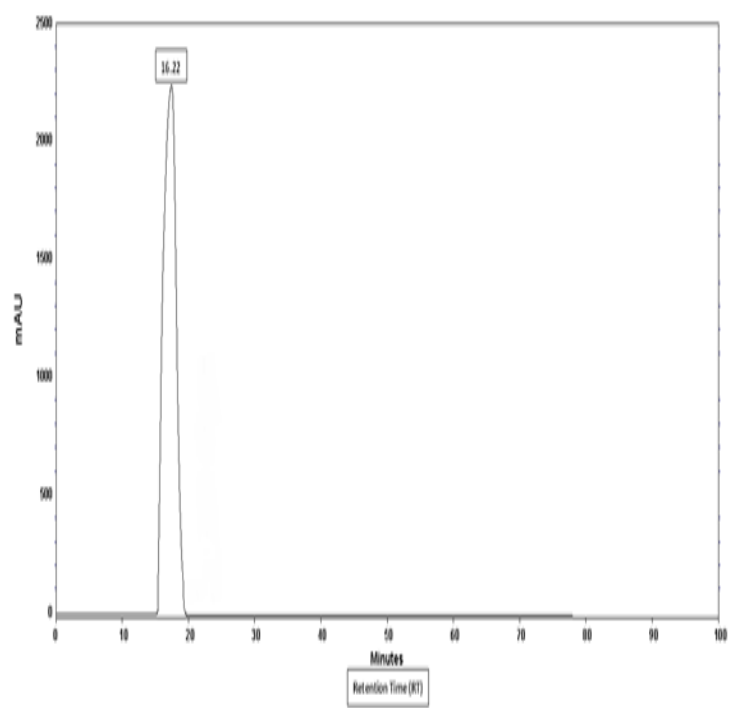

Figure 4. HPLC analysis of TTX standard (Authentic TTX).

\section{UV spectrum (Ultra Violet spectrophotometer) analysis}

The developed toxins were visualized as yellow spots under UV light at $365 \mathrm{~nm}$. In UV spectroscopy, TTX is generally determined by irradiating a crude toxin with UV light. A small amount of TTX is dissolved in $2 \mathrm{ml}$ of $2 \mathrm{M} \mathrm{NaOH}$ 
and heated in a boiling water bath for $45 \mathrm{~min}$. After cooling to room temperature, the UV spectrum of the solution is examined for characteristic absorptions, associated with C9base, 2-amino-6-hydroxymethyl-8hydroxyquinazoline, possibly formed from TTX and/or related substances, if present. In the analysis, the UV spectrum of the alkali decomposed compounds of TTX appears as a shoulder at near $276 \mathrm{~nm}$, indicating the formation of C9-base specific to TTX or related substances (Figure 5 and 6). A similar result was observed by Saito et al., 1987 used this method in experiments analyzing TTX and its derivatives in toxic puffer fish.

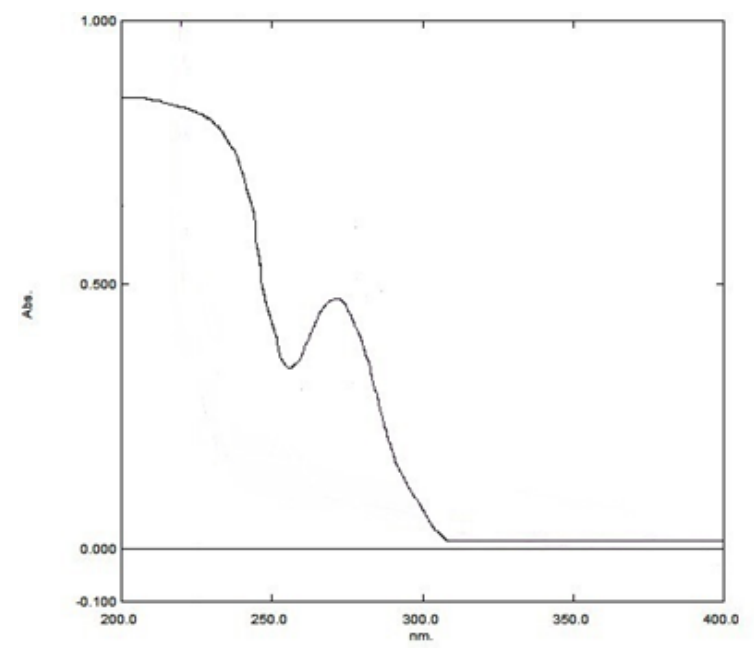

Figure 5. UV absorption spectra of TTX fraction from liver of Puffer fish, Lagocephalus sceleratus inhabiting Mediterranean sea, Egypt.

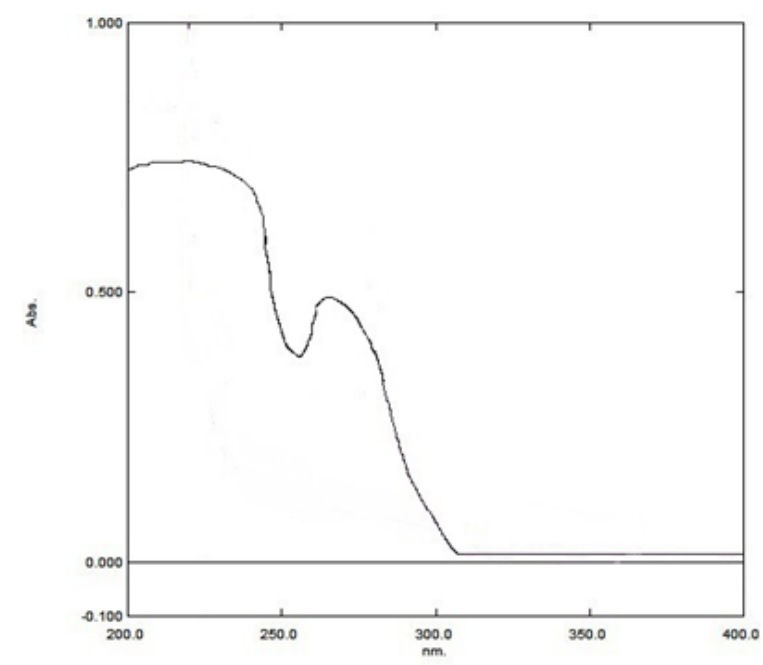

Figure 6. UV absorption spectra of TTX standard (Authentic TTX) fraction.

\section{Antimicrobial activity}

The antibacterial activity of the crude extracts of puffer fish $L$. sceleratus were tested against the bacterial strains. The results of the inhibition activity of the crude TTX extract isolated from the liver, skin and muscles of $L$. sceleratus is shown in the Table 1 as compared with the standard ampicillin in gram positive bacteria. The maximum anti-microbial activity of the crude TTX Bacillus subtilis was recorded for those from the liver followed by those of skin and then muscles; 17.51, 16.27 and 15.28 $\mathrm{mm}$ respectively. Their antimicrobial activities against Staphylococcus aureus showed 13.83, 12.75 and $11.30 \mathrm{~mm}$ respectively. Their minimum activity against Streptococcus agalactiae was 10.84, 11.44 and $12.68 \mathrm{~mm}$, for the crude extracts of TTX from skin, muscles and liver respectively as shown in the Figure 7.

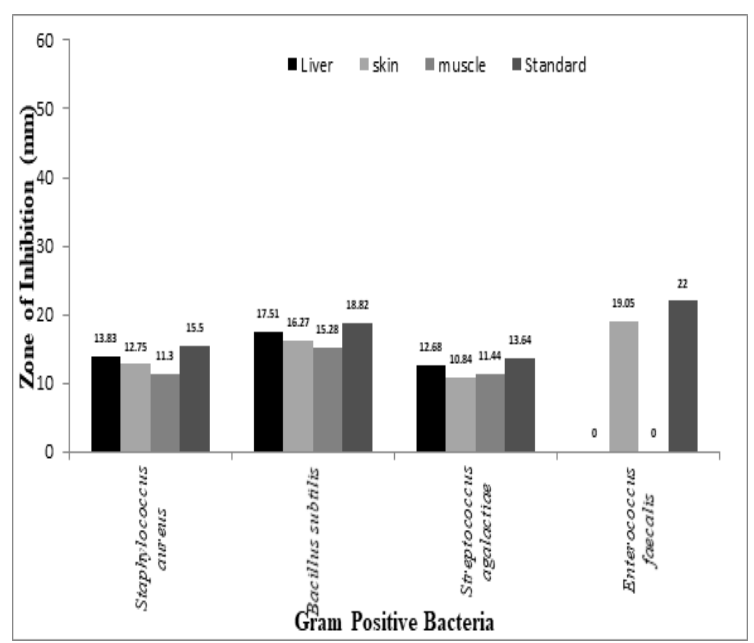

Figure 7. Antibacterial activity of TTX extracts of liver, skin and muscles isolated from Puffer fish, $L$. sceleratus with some gram positive bacteria against Ampicillin (standard).

The inhibition activity against $L$. sceleratus of the crude TTX extract isolated from the liver, skin and muscles is shown in the Table 2 as compared with the standard Gentamycin in gram negative bacteria. The maximum activity of the extract was shown for the liver TTX followed by those from skin and muscles against the Escherichia coli recording 22.24, 20.16 and $19.16 \mathrm{~mm}$, respectively. In case of Aeromonas veronii, the antimicrobial effects of the crude TTX of the liver was the highest followed with muscles and skin extracts as 20.49, 19.67 and $18.02 \mathrm{~mm}$, 
respectively in. On the other hand, the minimum activity against Vibiro cholerae was $8.08 \mathrm{~mm}$ for TTX in muscle, $8.45 \mathrm{~mm}$ in skin and $9.22 \mathrm{~mm}$ in the liver extract as shown in Figure 8 . The antifungal activity of the crude extracts of puffer fish $L$. sceleratus were tested against the fungal strains. The results of the inhibition activity of the crude extract of $L$. sceleratus are shown in Table 2 as compared with the standard fluconazole. The maximum activity against Aspergillus fumigatus was shown for of crude TTX of the liver followed by skin and muscles extract were shown, recording $19.21,17.11$ and16.27 $\mathrm{mm}$, respectively.

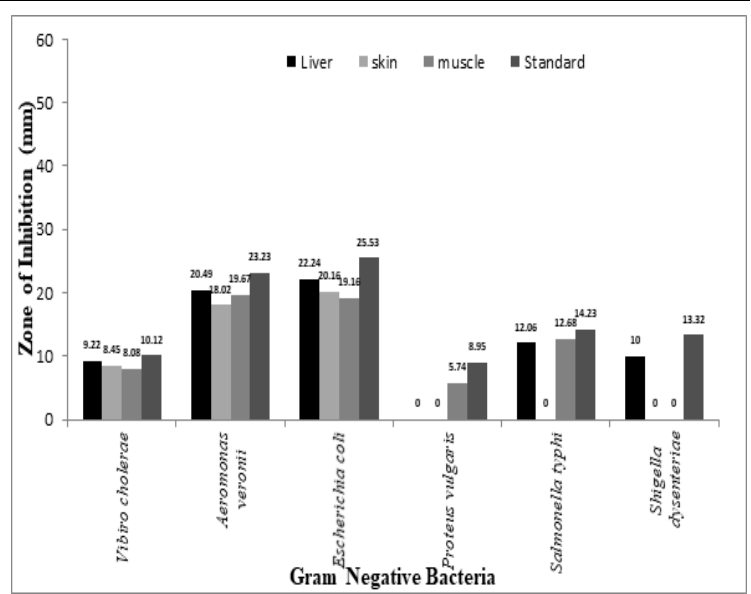

Figure 8. Antibacterial activity of TTX extracts of liver, skin and muscles isolated from Puffer fish, $L$. sceleratus with some gram negative bacteria against Gentamycin (standard).

Table 1: Seasonal TTX levels in different tissues isolated from Puffer fish, L. sceleratus $(\mu \mathrm{g} / \mathrm{g})$ using LC/MS/MS.

\begin{tabular}{|c|c|c|c|c|}
\hline Season & Sex & $\operatorname{Liver}\left(\dot{X} \pm S_{x}\right)^{1}$ & Skin $\left(\dot{X} \pm S_{x}\right)^{1}$ & Muscle $\left(\dot{X} \pm S_{x}\right)^{1}$ \\
\hline \multirow{2}{*}{ Winter } & Male & $25.37 \pm 0.49$ & $1.64 \pm 0.23$ & $0.77 \pm 0.27$ \\
\hline & Female & $30.33 \pm 0.56$ & $3.38 \pm 0.45$ & $2.26 \pm 0.45$ \\
\hline \multirow{2}{*}{ Summer } & Male & $4.04 \pm 0.74$ & $0.35 \pm 0.12$ & $0.66 \pm 0.27$ \\
\hline & Female & $21.04 \pm 0.49$ & $1.60 \pm 0.28$ & $1.10 \pm 0.31$ \\
\hline
\end{tabular}

(1) $\dot{\mathrm{X}} \pm$ Sx: Mean \pm standard deviation

Table 2. Antimicrobial activities of TTX extracts of liver, skin and muscles isolated from Puffer fish, L. sceleratus.

\begin{tabular}{|c|c|c|c|c|}
\hline Tested organisms & $\begin{array}{c}\text { Liver } \\
\left(\dot{X} \pm \mathrm{S}_{\mathrm{X}}\right)^{1}(\mathrm{ZOI} \\
\text { by }(\mathrm{mm}))^{2}\end{array}$ & $\begin{array}{c}\text { Skin } \\
\left(\dot{X} \pm S_{x}\right)^{1}(Z O I \\
\text { by }(\mathrm{mm}))^{2}\end{array}$ & $\begin{array}{c}\text { Muscle } \\
\left(\dot{X} \pm S_{x}\right)^{1}(Z O I \\
\text { by }(\mathrm{mm}))^{2}\end{array}$ & $\begin{array}{c}\text { Standard } \\
\left(\dot{\mathrm{X}} \pm \mathrm{S}_{\mathrm{X}}\right)^{1}(\mathrm{ZOI} \\
\text { by }(\mathrm{mm}))^{2}\end{array}$ \\
\hline Gram Positive Bacteria & \multicolumn{3}{|c|}{ Lagocephalus sceleratus } & Ampicillin \\
\hline Staphylococcus aureus & $13.83 \pm 0.36$ & $12.75 \pm 0.26$ & $11.30 \pm 0.77$ & $15.50 \pm 0.36$ \\
\hline Bacillus subtilis & $17.51 \pm 0.51$ & $16.27 \pm 0.62$ & $15.28 \pm 0.75$ & $18.82 \pm 0.42$ \\
\hline Streptococcus agalactiae & $12.68 \pm 0.08$ & $10.84 \pm 0.61$ & $11.44 \pm 0.31$ & $13.64 \pm 0.23$ \\
\hline Enterococcus faecalis & $N A^{3}$ & $19.05 \pm 0.29$ & NA & $22.00 \pm 0.50$ \\
\hline Gram Negative Bacteria & \multicolumn{3}{|c|}{ Lagocephalus sceleratus } & Gentamycin \\
\hline Vibiro cholerae & $9.22 \pm 0.65$ & $8.45 \pm 0.41$ & $8.08 \pm 0.17$ & $10.12 \pm 0.32$ \\
\hline Aeromonas veronii & $20.49 \pm 0.57$ & $18.02 \pm 0.64$ & $19.67 \pm 0.39$ & $23.23 \pm 0.67$ \\
\hline Escherichia coli & $22.24 \pm 0.96$ & $20.16 \pm 0.31$ & $19.16 \pm 0.92$ & $25.53 \pm 0.53$ \\
\hline Proteus vulgaris & NA & NA & $5.74 \pm 0.46$ & $8.95 \pm 0.63$ \\
\hline Salmonella typhi & $12.06 \pm 0.76$ & NA & $12.68 \pm 0.08$ & $14.23 \pm 0.64$ \\
\hline Shigella dysenteriae & NA & NA & NA & NA \\
\hline Fungi & \multicolumn{3}{|c|}{ Lagocephalus sceleratus } & fluconazole \\
\hline Candida albicans & $12.5 \pm 1.30$ & $13.17 \pm 0.47$ & $10.66 \pm 0.60$ & $16.99 \pm 0.48$ \\
\hline Aspergillus fumigatus & $19.21 \pm 0.59$ & $17.11 \pm 0.85$ & $16.27 \pm 0.67$ & $21.74 \pm 0.60$ \\
\hline Trichophyton rubrum & NA & $5.33 \pm 0.52$ & $6.21 \pm 0.89$ & $9.85 \pm 0.38$ \\
\hline
\end{tabular}

(1) $\dot{X} \pm$ Sx: Mean \pm standard deviation. (2) ZOI by $(\mathrm{mm})$ : Zone Of Inhibition measured by mile meter. (3)NA: No Activity. 
Their antifungal activities against Candida albicans showed that the activity of the crude TTX of skin was the highest followed by those of the liver and then muscles extract recording as 13.17, 12.50 and $10.66 \mathrm{~mm}$, respectively. On the other hand, the minimum activity against Trichophyton rubrum was $5.33 \mathrm{~mm}$ for TTX in skin and $6.21 \mathrm{~mm}$ for those in muscles extracts where no activity recorded for the crude TTX of the liver extract as shown in Figure 9.

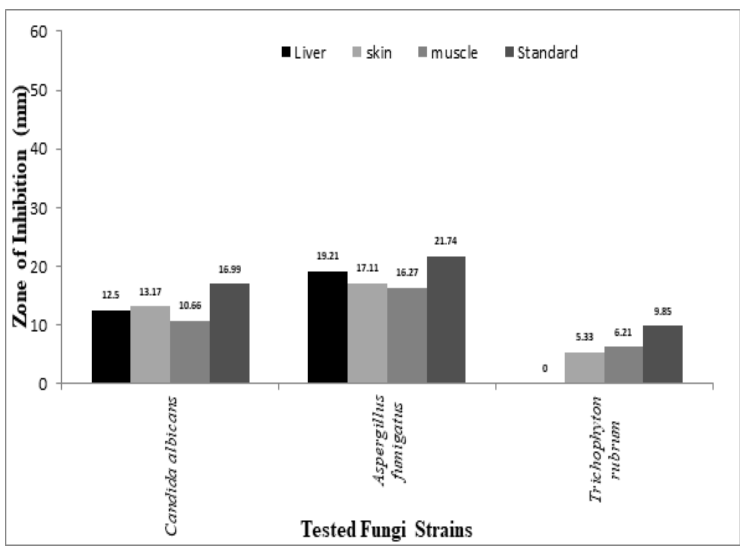

Figure 9. Antifungal activity of TTX extracts of liver, skin and muscles isolated from Puffer fish, $L$. sceleratus with some fungi strains against fluconazole (standard).

\section{DISCUSSION}

The antibacterial activity of fish has been known for many years and has been demonstrated in the mucous of several fishes. It was reported that epithelial tissues produce antimicrobial molecules which serve as the first line of a host defense against microbial invasion in vertebrates (Ganz, 1999). In this study, antimicrobial activity of skin extract of $L$. sceleratus showed activity against various bacterial and fungal organisms. The highest antibacterial activity was high against Enterococcus faecalis and Bacillus subtilis (gram positive bacteria), Escherichia coli and Aeromonas veronii (gram negative bacteria) The minimum activity was recorded against Streptococcus agalactiae (gram positive bacteria) and Vibiro cholerae (gram negative bacteria) The maximum antifungal activity was observed against Aspergillus fumigatus and Candida albicans where the minimum activity was recorded against Trichophyton rubrum by the skin extract of puffer fish $L$. sceleratus.
Similar results were also reported from the puffer fish $A$. hispidus from the Mandapam coast (Mohana and Khora, 2013) from $A$. immaculatus from the Parangipettai coast (Kumaravel et al, 2011) which reports antibacterial activity against various pathogens. The results clearly indicate that the bio toxin present in the puffer fish can be used potentially in pharmaceutical applications. Though this toxin is a health threat in its original form due to its binding ability, yet it shows potentials as a drug in lower doses.

Noguchi and Arakawa (2008) reported that extracts from gonads of $L$. sceleratus were extremely toxic (>1000 MU/g), where those of the liver, skin and muscles were less toxic (10$100 \mathrm{MU} / \mathrm{g}$ ), and intestinal one was moderately toxic (100-1000 MU/g); the muscle of this fish was generally toxic. Many researchers reported that the highest concentrations of TTX level in puffer fish were in gonads, following by the liver, intestines, skin and muscle tissue (Chua \& Chew, 2009; El-Sayed et al., 2003). Azman et al. (2014) reported that TTX levels in the liver, muscle and skin of $L$. sceleratus males were $24.7 \mu \mathrm{g} / \mathrm{g}, 30.0 \mu \mathrm{g} / \mathrm{g}$ and $0.51 \mu \mathrm{g} / \mathrm{g}$ respectively. The finding of liver and skin were nearly similar with this work but TTX levels in muscle tissue were more than the result of Azman in cold season.

El-Sayed et al. (2003) investigated the TTX level in 45 silver stripe blaasop puffer fish samples. Similar to our results, the highest values were found in the liver, muscle tissue and skin, as (converted from $\mathrm{MU} / \mathrm{g}$ to $\mu \mathrm{g} / \mathrm{g}$ ) $246 \mathrm{MU} / \mathrm{g}(54.12 \mu \mathrm{g} / \mathrm{g}), 127 \mathrm{MU} / \mathrm{g}(27.94 \mathrm{\mu g} / \mathrm{g})$ and $119 \mathrm{MU} / \mathrm{g}(26.18 \mu \mathrm{g} / \mathrm{g})$, respectively. It was considered that this case was related to the sensitivity of GC mass spectroscopy that used in research also, the different in species and founa between the previous study in Red Sea and the current study in Mediterranean Sea.

Dao et al. (2012) investigated the TTX level of L. sceleratus by HPLC and found TTX content in liver, skin and muscle tissue (MU/g) as $20.8(4.58 \mu \mathrm{g} / \mathrm{g}), 27.8(6.11 \mu \mathrm{g} / \mathrm{g})$ and 58.7 $(12.91 \mu \mathrm{g} / \mathrm{g})$, respectively, but they especially found high levels of toxins in skin and muscle tissue compared to our study. This can be due to the environmental conditions, geographical differences and feeding regime. First TTX 
content in puffer fish investigated with chromatographic method was carried out by Rodríguez et al. (2012) in the European waters. They investigated TTX levels of $L$. sceleratus caught from the Aegean Sea by LC-MS-MS. TTX content ranged from 3.37 to $32.15,0.53$ to 3.40 and 0.66 to $3.07(\mu \mathrm{g} / \mathrm{g})$ in liver, skin and muscle, respectively. The results of this study are nearly similar with our study in terms of TTX levels in liver, skin, and muscle tissue, with the consideration that the sex and seasonal factors not taken in Rodríguez study to differentiation in TTX levels between tested organs.

Many researchers reported that the toxicity of puffer fish was dependent on reproduction season, since the reproductive period for most species of puffer fish was from late spring to summer. Thus, toxin levels in the fall and winter season were the lowest (EISayed et al., 2003; Hwang \& Noguchi, 2007). However, $\mathrm{Yu}$ and $\mathrm{Yu}$ (2002) reported that Takifugu niphobles and Takifugu alboplumbeus species did not show toxic effects in the reproduction period. It was similarly indicated by Katikou et al. (2009) and Rodríguez et al. (2012), TTX level of L. sceleratus species, caught from the Mediterranean Sea, was higher in the autumn and winter season. It is thought that this situation may be specific in the Mediterranean and Aegean Sea. The effects of seasonal variations toxin levels should be investigated with more scientific research.

The Minimum Lethal Dosage (MLD) of TTX for the average weight female $(50 \mathrm{~kg}$ ) was estimated to be $2 \mathrm{mg}$ (Katikou et al., 2009). This is equivalent to $10 \mathrm{MU}$ TTX per $\mathrm{g}$ of edible part (Miyazawa \& Noguchi, 2001). Because males and females cannot generally be distinguished by fishers or consumers easily, fish meat should not be eaten in the winter without prior testing, although more data collection is strongly recommended before making any such change. Further studies should also focus on the gain into fisheries economy or a drug for the pharmacy sector.

\section{REFERENCES}

Aydin M (2011). Growth, reproduction and diet of puffer fish (Lagocephalus sceleratus Gmelin, 1789) from Turkey's

Mediterranean Sea coast. Turkish Journal of Fisheries and Aquatic Sciences. 11: 589-596.

Aydin M, Tufan B, Sevgili H and Köse S (2013). Seasonal changes in proximate composition and fatty acid profile of puffer fish (Lagocephalus sceleratus Gmelin, 1789) from the Mediterranean Sea of Turkey. Journal of Aquatic Food Product Technology. 22(2): 178-191.

Azman AMN, Samsur $M$ and Othman $M$ (2014). Distribution of tetrodotoxin among tissues of puffer fish from Sabah and Sarawak waters. Sains Malaysiana. 43(7): 1003-1011.

Chamandi SC, Kallab K, Mattar H and Nader E (2009). Human poisoning after ingestion of puffer fish caught from Mediterranean Sea. Middle East journal of Anesthesiology. 20(2): 285-288.

Chua HH and Chew LP (2009). Puffer fish poisoning: A family affair. Medical Journal of Malaysia. 64(2): 181-182.

Dao VH, Nguyen TD, Nguyen TH, Takata Y, Sato S, Kodama M and Fukuyo Y (2012). High individual variation in the toxicity of three species of marine puffer in Vietnam. Coastal Marine Science. 35(1): 1-6.

Ellis AE (2012). Non-specific defense mechanisms in fish and their role in disease processes. Dev Biol Stand. 49: 337-352.

El-Sayed M, Yacout GA, El-Samra M, Ali A and Kotb SM (2003). Toxicity of the Red Sea puffer fish Pleuranacanthus sceleratus "El-Karad". Ecotoxicology and Environmental Safety. 56(3): 367-372.

Finney DJ (1971). Probit analysis third edition. Cambridge Univ. Press. Pp. 333.

Ganz T (1999). Defensins and host defense. Science. 266: 420-421.

Holder IA and Boyce ST (1994). Agar well diffusion assay testing of bacterial susceptibility to various antimicrobials in concentrations non-toxic for human cells in culture. Burns. 20: 426-429.

Hwang DF and Noguchi T (2007). Tetrodotoxin poisoning. Advances in Food and Nutrition Research. 52: 141-236. 
Katikou P, Georgantelis D, Sinouris N, Petsi A and Fotaras $T$ (2009). First report on toxicity assessment of the lessepsian migrant puffer fish Lagocephalus sceleratus (Gmelin, 1789) from European waters (Aegean Sea, Greece). Toxicon. 54(1): 50-55.

Khora SS (2013). Marine Fish-Derived Bioactive Peptides and Proteins For Human Therapeutics, Int J Pharm Pharm Sci. 5(3): 31-37.

Khora SS (1991). Toxicity studies on puffer fish from tropical waters. D. Ag. Thesis. Tohoku University, Sendai Japan.

Kumaravel K, Ravichandran S, Sharmila J, Manikodi D and Mauro D (2011). In vitro Antimicrobial Activity of Tissue Extracts of Puffer fish Arothron immaculatus Against Clinical Pathogens. Chinese J Nat Medicines. 9(6): 446-449.

Miyazawa K and Noguchi T (2001). Distribution and origin of tetrodotoxin. Toxin Reviews. 20(1): 11-33.

Mohana PK and Khora SS (2013). Antimicrobial, Hemolytic and Cytotoxic activities of the Puffer Fish Arothron hispidus from the Southeast Coast of India. Int J Drug Dev Research. 5(2): 317- 322.

Noguchi T and Arakawa O (2008). Tetrodotoxin-distribution and accumulation in aquatic organisms, and cases of human intoxication. Marine Drugs. 6(2): 220-242.

Noguchi T and Ebesu JS (2001). Puffer poisoning: Epidemiology and treatment. Toxin Reviews. 20(1): 1-10.

Onoue Y, Noguchi T and Hashimoto K (1984). Tetrodotoxin Determination Methods: Sea food toxins. American Chemical Society, Washington, DC, 345-358.

Rajamanikandan S, Sindhu T, Durgapriya D, Anitha JR, Akila $S$ and Gopalakrishnan VK (2011). Molecular docking and QSAR studies on bioactive compounds isolated from marine organisms into the MUC1 Oncoprotein. Int J Pharm Pharm Sci. 3: 168-172.
Randall J E (1983). Red Sea Reef Fishes. IMMEL publishing limited, U.K. London. 192.

Ravichandran S, Kumaravel K, Rameshkuma G and Ajithkumar TT (2010). Antimicrobial peptides from the marine fishes. Res J Immunol. 3(2): 146-156.

Rodríguez $\mathrm{P}$, Alfonso $\mathrm{A}$, Otero $\mathrm{P}$, Katikou $\mathrm{P}$, Georgantelis D and Botana LM (2012). Liquid chromatography-mass spectrometry method to detect tetrodotoxin and its analogues in the puffer fish Lagocephalus sceleratus (Gmelin, 1789) from European waters. Food Chemistry. 132(2): 1103-1111.

Saito T, Kanoh S, Noguchi T, Shida $Y$ and Hashimoto K (1987). Occurrence of anhydrotetrodotoxin in several nontoxic species of puffer. In "Progress in venom and toxin research" (P.Gopalakrishnakone and C.K.Tan, ed.) 314-324. National University of Singapore, Singapore.

SAS (Statistical Analysis System) (2002). SAS/ STAT user's guide release 6.03 edition. SAS Institute Inc. Cary, North Carolina, USA.

Silva $M$, Azevedo J, Rodriguez $\mathrm{P}$, Alfonso A, Botana LM and Vasconcelos V (2012). New gastropod vectors and tetrodotoxin potential expansion in temperate waters of the Atlantic Ocean. Marine Drugs. 10(4): 712-726.

Streftaris $N$ and Zenetos A (2006). Alien marine species in the Mediterraneanthe 100 'Worst Invasives' and their impact. Mediterranean Marine Science. 7(1): 87-118.

$\mathrm{Yu}$ CF and Yu PHF (2002). The annual toxicological profiles of two common puffer fish, Takifugu niphobles (Jordan and Snyder) and Takifugu alboplumbeus (Richardson), collected along Hong Kong coastal waters. Toxicon. 40(3): 313-316. 